\title{
Development of E-Government to Support the Competency Improvement of State Civil Servants in the Regional Civil Service Agency in North Central Timor District
}

\author{
Irenius $\mathrm{Abi}^{*} \quad \mathrm{MNBC}$ Neolaka Frans Gana \\ Masters Program in Administrative Sciences, Postgraduate Program, University of Nusa Cendana Kupang, East \\ Nusa Tenggara, Indonesia
}

\begin{abstract}
A serious problem faced by regional civil service agency in North Central Timor Regency is the unavailability of complete, accurate and up-to-date staffing data, so that the effort of civil servants competencies development was overlapping. The Requirement for staffing data management systems based on information technology that compiles staffing data simplify is very urgent to be met. The purpose of this study is to analyze the success element of e-goverment development (support, capacity, value, willingness and local culture) and to analize obstacles of e-goverment development to support competence development of the Civil servants at regional civil service agency of North Central Timor Regency. This type of research is descriptive qualitative. The informant selection technique is purposive, with nine informants. The results showed that the elements of support, capacity, and local culture was not supporting the development of e-government, while the elements of value and willingness had supported; obstacles in the development of e-government include e-readiness, the absence of egoverment regulation, lack of availability of human resources and infrastructure resources as well as the lack of budget from the government finances, and the local culture of civil servants that not concern to increase their ability on Information and Communication Technology (ICT. The Government of the North Central Timor Regency, particularly, regional civil service agency needs to increase the readiness of elements of support, capacity and local culture to support the successful development of e-government.
\end{abstract}

Keywords: e-government, element of success, civil servants competence

DOI: $10.7176 / \mathrm{DCS} / 10-11-06$

Publication date: November $30^{\text {th }} 2020$

\section{Introduction}

The application of information technology in the government sector is known as electronic government or egovernment. E-government is the use and utilization of information technology by the government in order to create communication between the government, society, the business world and other parties interested in providing services instantly and accurately. In simple terms, e-government or government digital is an activity conducted by government by using information technology support in providing services to the public. ${ }^{1}$

The success or failure of the government in applying information technology to the government is very much dependent on the expertise of civil servant. The lack of civil servant expertise and competence is one fundamental issue for all institutions governance in giving public service. ${ }^{2}$

Data from the State Civil Service Agency as of June 30, 2019, shows that there are 4,286,918 civil servants in Indonesia, which $36.67 \%$ still have education below bachelor degree (S-1) . ${ }^{3}$ Criticism of the low quality of service for civil servants is always associated with the professionalism and competence of the employees.$^{4}$ Professional and highly competent State Civil Servants, as mandated by Law Number 5 of 2014 concerning State Civil Servants and are desired by all parties, until now is still a dream rather than a reality. ${ }^{2}$

Policies regarding the development of human resource competencies in order to obtain resources with good performance should be related to the type and nature of development provided to meet the needs of qualified personnel. Regional Government Organizations should pay attention to the needs of performing personnel who have competence according to their service fields because of these personnel is the spearhead of governance or development. ${ }^{5}$

Regional Civil Service Agency (BKD) play an essential role in fostering and implementing the management of the civil servant. One of the duties and functions of the Regional Civil Service Agency is to manage and develop a competency-based civil servant staffing information system that is supported by a comprehensive archival information system (Law Number 5 of 2014). The availability of accurate and comprehensive data will assist in managerial decision making regarding personnel competency development planning. ${ }^{2}$

Data from the Regional Civil Service Agency for North Central Timor Regency (TTU) in March 2020 shows that the number of the civil servant in Timor Tengah Utara Regency is 5,144 people, where almost half (43.49\%) are still educated below S-1, 83.59\% are in advantageous positions.

Leadership Training (PIM) as many as 99 people (11.73\%) from 844 structural employees, while the rest $(88.27 \%)$ have not participated in the training. The number of employees with practical positions who have 
attended functional education and training, data are not available at the BKD of TTU Regency.

Unavailability of data on employees who have and have never attended training as well as the types of training they have participated in create the overlapping implementation of functional training. Retrieval of initial data at the Health Office through interviews with the Head of the Health Office shows that the mechanism for determining an apparatus to be included in the Education and Training or Technical Guidance is subjective so that cases arise such as employees who have attended training for available positions as nurses being re-enrolled in training for health promotion positions. Meanwhile, there are still employees with an education background that suitable for the available positions but have never participated in any training for health promotion positions . This contradicts Article 203 paragraph three of Government Regulation Number II of 2017 concerning the management of Civil Servants which states that every Civil Servant has the same rights and opportunities to be involved in competency development. .This causes the Regional Civil Service Agency to experience difficulties in analyzing, formulating policies, planning, implementing and evaluating its activities relating to the development of civil servants competencies.

An accurate and up to date State Civil Service Database is needed to support the development of the competence of the civil servants.

Realizing the importance of the availability of complete and accurate personnel data and information, the Regional Civil Service Agency of Timor Tengah Utara Regency needs to implement a personnel information system based on information technology.

A government system that uses information technology as the primary supporting tool for providing services and information to the public is known as e-government. Three elements of success must be considered seriously so that e-government development can develop adequately according to the stages of e-government. These elements are support, capacity, and value (Indarjit, 2016), plus the elements of willingness and local culture (Moon, 2008 in Nugroho, 2008).

The availability of complete, accurate, and up to date personnel data is an urgent need to be fulfilled. Therefore Regional Personnel Bodies need information technology-based personnel data management system in the form of an application that makes it easy to collect personnel data. Efforts that have been made were to launch the Abimaus Application in December 2018. However, this application turns out to be cannot be implemented because its launching is not accompanied by a legal/regulatory basis that regulates and budget support from the local government. Learning from these failures, the authors are interested in conducting studies on the elements of successful e-government development and the obstacles in developing e-government in the scope of work of the Regional Civil Service Agency.

The purpose of this research is to analyze the successful elements development of e-government (support, capacity, value, willingness and local culture) and analyzing the hindrance to the development of e-Government. Furthermore, support the competence of the Civil servants in the Regional Civil Service Agency for the North Central Timor Regency.

\section{Methodology}

This research is a descriptive study with a qualitative approach. There are nine informants in this study who were taken purposively. The research focus includes elements of support, capacity, value, willingness, local culture and limitations to e-government development. The data collection technique was carried out through in-depth interviews, observation and documentation study. Data analysis consists of steps such as data reduction, data presentation and concluding. Researchers used triangulation of data source and collection to test the validity of data related to the research problem.

\section{Result and Discussion \\ 1. Elements of a Success in E-Government Development in the Regional Civil Service Agency of Timor Tengah Utara Regency \\ a. Support}

Support is an essential element in the development of e-government. The primary part in the support element is the support from the leadership element. Leaders must have the political will (political will) to develop egovernment because this will involve the entire process of e-government. It means that leaders not only have to be smart in terms of drafting concepts but must also be great motivators in the implementation phase (action). Without an element of political will, various development initiatives and development of e-government cannot run well. ${ }^{6}$

The results of the interview with the Head of the Organizational Division indicate that the goodwill of the regional Head and the readiness of the local government in preparing resources is fundamental in implementing e-government

This is in line with research conducted by Atthahara (2018) which states that there is a need for support or what is commonly called political will from public officials so that the e-government concept can be applied. 
This is also following the theory put forward by Indrajit (2016), where the bureaucratic culture tends to work based on a "top-down" management model. Support for the implementation of an effective e-government program must start from government leaders who are at the highest level before spreading to the levels below. ${ }^{6,7}$

The statement of the Head of Organization was strengthened by statements from the Regent and the Head of the Regional Civil Service Agency who supported the realization of e-government. This support will be expressed in the form of policies, regulations, and financial support, infrastructure and other resources. This support is still limited to the concept of agreeing on an e-government framework and the desire to allocate several resources. This support is still a political will. BKD currently does not have a regulation regarding egovernment management. This is in line with the results of research conducted by Setiani and friends (2018) which found that there is no regulation in the implementation of e-government in Kendal Regency, even though the Kendal Regent supports e-government through a predetermined vision and mission. ${ }^{8}$ Reddick's theory (2011) in Hardjaloka (2014) which states that in order to implement e-government in each region, local governments must issue a regional regulation that regulates the obligation to implement e-government. ${ }^{9}$ Currently in TTU district only has Electronic Based Government master plan.

Another support aside from readiness to form regulations is socialization. Interviews with the Head of service for youth education and sports (PKO), Head of BKD, Head of Agriculture and Head of Organization show that the application will provide maximum benefits if socialization is carried out to all each regional organization (OPD), besides that there must be training for operators/admins in each (OPD). The results of this interview are in line with the research of Batubara and Helmy (2019) which states that socialization is an essential means for the government to support the successful implementation of e-government in the regions. Socialization will make the public aware of any information related to the existence of e-government and participate in building the e-government. ${ }^{10}$ This research is in line with Indrajit's (2016) theory which states that the development of e-government Should be followed up by disseminating the concept of e-government evenly, continuously, consistently and thoroughly to all bureaucrats through various sympathetic campaigning methods.

Researchers argue that the support of the Regent and OPD leadership must be followed up by the existence of regulation or legal to regulate e-government management because implementation requires action and provision of facilities and not just a concept. Immediate budget planning to support activities that can implement e-government successful is necessary, such as socialization activities for all civil servants in Regional Apparatus Organizations as well as training or Bimtek for admins/operators. BKD and all OPDs need to consider about adequate operational, maintenance and e-government budget allocation in the Local Government Budget (APBD) as well as placing an e-government program to support the enhancement of civil servants competencies as a priority scale in regional development.

\section{b. Capacity}

Capacity is an element of capability or empowerment from the government in making the e-government well established.

\section{1) Financial resources}

Financial resources must be prepared as well as possible because, without an adequate budget, the implementation of e-government in an area will be impossible. Financial resources are needed to support the availability of other resources, such as information technology infrastructure and human resources as well as for additional training of employees, equipment maintenance and other costs ${ }^{11}$

The results of interviews with the Head of BKD indicate that the required funds for e-government development have not been well planned. These are supported by the results of a documentation study of the state implementation documents of local government agency (DPA-SKPD) budget for the provision Of civil servants competency development is IDR 263,711,880. Most of the budget is spent on equipment and machines such as servers, bandwidth, AC, UPS, software and routers, the rest is for stationery and consumption fees.

Results of interviews witH a technology expert indicated that to build a web-based application requires funds of approximately IDR 200,000,000. While, Budget in the DPA-SKPD (IDR 263,711,880) it is considered that they will not be able to finance the development of the application and guarantee that the application will operate adequately Because it does not include costs for application development, network maintenance and other supporting activities such as dissemination.

The results of interviews and documentation studies indicate that there are limitations in financial resources. This is in line with research conducted by Lestari and Widowati (2015), where the development of e-government in the City of Salatiga is experiencing obstacles due to limited financial resources. This matter Is because the proposed budget is sometimes not approved by the Development Planning and Research Agency (Bapelitbangda). ${ }^{12}$ The results of this study contradict the research of Atthahara (2018) which found that the Purwakarta Regional Government spent quite a lot of budget for e-government development especially in terms of socialization because it had to invite various media Local and national print. ${ }^{7}$ The results of the research support the theory of Sosiawan (2008) and Ordiyasa (2015) which states that budget is vital in the development of e-government. The failure of e-government in Indonesia is partly due to budget constraints. The budget is a 
severe problem for the government in implementing e-government. ${ }^{13,14}$

Limited financial resources are due to the inadequate preparation of the work plan and budget (RKA). The estimation of the market price used is not the same as the actual situation and the conditions used as the basis for budgeting have progressed much differently than planned, besides that planners do not take into account other supporting activities. Financial limitations are also due to a $10 \%$ cut in transfer funds for handling the Covid-19 pandemic.

Researchers argue that budget planners should plan well the needs related to e-government development, not only application development, but also take other supporting activities. Another financing alternative is a cooperation between OPDs so that supporting activities that can be done are shared. Planning of e-infrastructure development budget

The government should be done in stages, for example, this year building the application and providing supporting facilities, next year it is budgeted for an application upgrade.

\section{2) Information Technology Infrastructure Resources}

Infrastructure is one crucial element in supporting the success of e-government carried out within a government institution. For this reason, in managing e-government, it is necessary to pay attention to the existence of an adequate information technology infrastructure in order to create effective and efficient e-government.

The results of interviews with the Head of BKD indicate that the facilities and infrastructure to support the implementation of e-government are still inadequate at BKD. These limitations include the availability of buildings, servers, bandwidth, UPS, and routers. This is one of the reasons the Abimaus application launched cannot be operated and developed.

The results of this interview support Margiyanti's (2016) research found that limitation technological infrastructure resources are an obstacle in carrying out e-government-based tasks at the Pringsewu District Cooperatives and SMEs. ${ }^{16}$.These results are consistent with the research results by Sitokdana (2019), which states that infrastructure problems have a significant influence on the implementation of e-government in eastern Indonesia. It is also in line with Indrajit's (2016) theory, namely the availability of information technology infrastructure is $50 \%$ of the key To the successful development of the concept of Electronic Government. ${ }^{17}$

Results of interviews with Head of Health agency and the Head of the Agriculture Office showed that the technological infrastructure in OPD, such as the availability of wifi, computers, scanners, and buildings, is sufficiently available. The results of the researchers' observations showed that the OPD already has a local computer network or local area network and the internet network. The results of interviews with the head of communications, informatics and statistics agency showed that all districts in the TTU already has an internet network. However, some places are still weak in signals.

This shows that the information network infrastructure in the District. TTU has supported implementing egovernment. The results of this interview are in line with Azwaria's (2013) research which found that the technology infrastructure in implementing LPSE and SIUJAKI at the Makassar City Regional Secretariat Office was adequate. The number of computers is sufficient, and the internet network as one of the main supports is also functioning properly to provide easy access for the public. ${ }^{18}$

The results of this study indicate that limited technology infrastructure resources are more experienced by BKDs than OPDs. This problem becomes serious because BKD is the main admin in operating the application. The results of this study are consistent with the results of research by Hidayat et al. (2011), the availability of computer units, data communication infrastructure, and computer networks is a pre-requisite, considering that egovernment applications can only function optimally if the infrastructure is available. ) in the results of his research in Pati District, it shows that IT infrastructure is an important element in implementing e-government because it is a tool in its implementation. Without the supporting infrastructure, and electronic government cannot be created. ${ }^{11}$

The author has the view that BKD must strive to fulfil infrastructure, which includes the fulfilment of supporting facilities, maintenance and management of well-planned information technology infrastructure.

\section{3) Human Resources}

Availability of adequate human resources will encourage the development and implementation of e-government, on the other hand, if the available human resources do not meet the desired expectations, then this will hamper the implementation of e-government.

The readiness of human resources, especially in the IT sector,must be a priority in implementing egovernment. ${ }^{15}$

The results of the interviews with the Head of BKD show that the BKD has limited human resources in implementing e-government. This is supported by the statement of the Head of Agriculture and Health Office, which states that the Bachelor of Informatics / Computer Engineering is still very limited in their institutions. The current personnel do not have an educational background informatics engineering but have ability in technology informatics in a self-taught manner. Results interviews align with research Angguna (2017), which shows that the Department of Cooperatives and SMEs in Malang City does not have human resources who have 
the ability in the IT field so that it harms the quality of services provided.20 The results of this interview also support the research of Rakhmawanto (2017) where the lack of quantity and quality of human resources Personnel management at BKD is one of the inhibiting factors for the development of an IT-based ASN management system. ${ }^{2}$

The results of interviews with the TTU Regent indicated that limited human resources were a severe problem. Attempts were made to address this problem is to prepare the operator's resources, both educationally and mentally.

Head of BKD, head of Agriculture and suggested that efforts to solve the problem of human resources limitations are to Increase the number of personnel with a background in informatics engineering education and increase the capacity of personnel through training, technical guidance or on the job training. The results of this interview are in line with the research of Batubara and Helmy (2019), where IT training for employees can support the successful implementation of e-government. ${ }^{10}$ These results are also in line with Masyhur's research results.

(2013), the problem faced in the development of e-government in the City of Parepare is the low number of qualified ICT human resources. Recommendations given through the results of this study are to improve the quality of human resources through ICT conventional training, online training, providing ICT scholarships, and benchmarking. Masyhur (2013) states that training aims to improve the quality of human resources both technically and non-technically. ${ }^{21}$

\section{c. Value}

Various policies will not be implemented if they do not have an element of value or benefit in them. The application of electronic government has various benefits. ${ }^{11}$ Setiani and friends (2018) stated that the benefits here are not only felt by the community (service users) but also by the government (service providers) ${ }^{8}$

The results of interviews with the Kadis Kominfotik show that the application to be built is expected to provide benefits in the form of bureaucratic services that are more effective, efficient and less paper. The results of this interview are in line with the research of Arif et al. (2013), the Kudus Regency Government benefits from e-government, namely increased efficiency and effectiveness in providing services to the community and stakeholders. Lestari and Widowati's research (2018) also shows the same thing, where the Salatiga City Government benefits from e-government. These benefits include increasing government transparency, which can improve services to the public in a faster, cheaper and more comprehensive manner and are paperless.

The Head of Health Office hopes that e-government will provide benefits in the form of helping leaders assess their subordinates more objectively.

This is following the theory of Dash and Pani (2016) which states that one of the benefits of implementing e-government is that it can increase transparency, control, and accountability of governance in the context of implementing the concept of Good Corporate Governance. E-government helps to increase transparency in the decision-making process by providing easily accessible information

The Head of BKD hopes that the e-government can provide benefits in the form of providing complete, accurate and up to date personnel data so that it can be used as a basis for staffing managers in the Regional Civil Service Agency to take policies related to the development of ASN competencies, in addition to all forms of ASN resource development. Can be done centrally in the BKD. The results of this interview are under the objectives of developing e-government (Inpres No. 3 of 2003 where one of the objectives is the establishment of a management system and work processes that are transparent and efficient and facilitate transactions and services between government agencies and autonomous regional governments.

The Head of Agriculture and the Kadis Head hope that the development of this e-government will provide benefits in the form of faster data processing, saving time and minimizing data processing errors so that they can present valid, definite and correct personnel data/information.22 This is in line with the benefits of e-government stated by Kumar and friends (2007), namely the availability of Continuous service, time-saving and error rate reduction. $^{23}$

\section{d. Wilingness}

The community as the object of the implementation of e-government is the main element supporting the successful implementation of e-government in an area. Willingness or willingness is one of the elements of the success of e-government because,without the willingness of the user community as the object of implementing an electronic-based government, the implementation of e-government itself will not succeed. The community must obtain maximum use of the facilities provided by the government. ${ }^{22}$

Results of interviews with the Head of Health and Agriculture Office: OPD welcomes the plan to develop egovernment. This shows that OPD, as a user has the willingness to use this application. The results of this interview are in line with the results of Napitupulu's (2015) research: factors of high public interest and factors of awareness from the government and society are included in the 50 factors of successful implementation of egovernment in Bogor City Government. ${ }^{24}$ The results of this interview are contrary to the results of research by 
Purwandani et al. (2012) ) where the everyday use of e-government facilities in Kab. Pati because the public's willingness to use e-government facilities is still lacking. This is because people access the internet only for entertainment needs rather than accessing public information. ${ }^{11}$

The results of interviews with the Head of BKD indicate that the implementation of e-government is an obligation. OPD has no other choice in order to carry out bureaucratic reform in the field of civil servant competency development other than implementing e-government. The results of this interview are in line with the spirit implied in Presidential Instruction No. 3 of 2003, namely that the government must be able to take advantage of advances in information technology to improve the ability to process, manage, distribute, and distribute information and public services.

The government must immediately carry out a process of transformation towards e-government to eliminate the boundaries of bureaucratic organizations and form a network of management systems and work processes that allow government agencies to work in an integrated manner to simplify access to all public information and services. $^{25}$

Researchers argue that the willingness of DPOs is an essential key to the success of e-government development. BKD, as the application manager, should be able to cultivate the willingness aspect of OPD to continue to utilize this application by conducting socialization both conventionally and through online media continuously. Besides, it is necessary to plan to upgrade the application periodically so that the application provides maximum benefits to the user.

\section{e. Local Culture}

Culture is something that must exist in a human group or organization. Every human being lives in a society that has a culture that is different from the cultures of other communities. Every culture will consciously or not influence our attitudes and behaviour in various aspects of life. ${ }^{26}$

The results of interviews with the PKO Kadis show that civil servants are not fully literate with computers and the internet, so there is an assumption that the use of information technology is a burden. This is related to the culture that grows among civil servants. The Head of BKD said that the local culture originated from civil servants habits, such as not wanting to be bothered, not wanting to be dizzy, undisciplined, indifferent and lazy. These cultures make them reluctant to learn ICT knowledge and skills. The results of this interview are in line with the research of Purwandani et al. (2012) and Lestari and Widowati (2018). They found that people are not fully literate with computers and the internet because they do not have the desire to study computers / the internet and prefer manual methods..$^{11,12}$

Ananto (2005) states that leaders who are unable to manage the organization well will produce an organizational culture that tends to be damaging, such as indifference, indifference, indiscipline, and laziness. ${ }^{27}$

This will affect the behaviour of its members. Mustafid (2017) argues that a strong culture in an organization can provide coercion or encouragement to its members to act or behave as expected by the organization. Regarding the development of e-government. ${ }^{26}$ Rozikin et al. (2020) stated that errors in organizational culture management changes caused the failure of e-government. Therefore organizational culture must be appropriately managed so that it can produce positive member behaviours. ${ }^{28}$

Researchers argue that the local culture of civil servants can be improved by making the use of the internet and other information technology as an organizational culture in every office activity and bureaucratic service. Indirectly, they will make Information and Communication Technology (ICT) part of its culture.

\section{Internal obstacles on Development of E-Government in the Civil Service Agency North Central Timor district}

The implementation of e-government as innovation among government organizations requires appropriate change management so that its implementation can run successfully. This is because implementing egovernment also means carrying out a series of cultural changes from traditional approaches to management and from the era before information and communication technology to the era of the development of highly sophisticated information and communication technology. This is what causes the development of e-government always to encounter obstacles. ${ }^{29}$

The results of interviews with the Head of PKO and the Head of BKD show that the biggest obstacle to the development of e-government comes from financial resources. The budget for building applications was cut and diverted for handling Covid-19. The results of this interview are in line with the results of research by Lestari and Widowati (2015): financial obstacles in developing e-government in the City of Salatiga are since the proposed budget is sometimes crossed out or not approved by Bapelitbangda. ${ }^{12}$

The results of interviews with the Head of PKO and Kadinkes show that another obstacle in the development of e-government, namely e-readiness (ASN readiness). The results of this interview are in line with Nugraha's research (2018) which shows that ASN's readiness to utilize information technology is still low, especially for employees who are almost entering retirement. This result is contrary to research. ${ }^{30}$ Susanto (2011) where the level of e-readiness in Terong Village is quite good (community knowledge about IT and the ability to use the internet).$^{31}$ 
The results of the interview regarding the five elements of success can be identified as follows:

a. There is no regulation.

Support is still in the form of political will. Not yet realized in the form of an official regulation.

b. Limited Financial Resources.

The budget is not sufficient to build and operate applications. The budget was cut and diverted for handling Covid-19.

c. Limited Infrastructure Resources

BKD does not have servers, UPS, bandwidth, routers and adequate buildings/rooms.

d. Human resource limitations

BKD as the primary admin only has 1 IT staff, while OPD does not have IT personnel

e. ASN Local Culture

ASN tends to be lazy, indifferent, undisciplined and does not want to improve their ICT skills.

E-government development is often constrained by several factors, including the lack of adequate human resources (skills and managerial in managing local government sites). Local government forces existing human resources to carry out e-government activities. In several regional government offices, there are only 3-5 civil servants who have ICT skills, some of whom do not necessarily have a bachelor's background in informatics or electrical engineering. Other obstacles are inadequate infrastructure, expensive ICT facilities and infrastructure. ${ }^{13}$

The results of this study are also in line with the results of research by Purwandani et al. (2012) which show that the development of e-government in Pati Regency is experiencing obstacles because there is no regional regulation that regulates the implementation of e-government, limited financial resources, IT infrastructure, limited human resources, low capabilities. The community uses e-government facilities because they are not computer/internet literate, and the local culture tends to prefer manual methods rather than online.

Researchers argue that BKD should continue to encourage local governments to issue regulations governing the implementation of e-government immediately. Local governments (BKD and OPD) need to include the egovernment budget in the APBD and make the e-government program a priority scale. Integrated human resource education and training in the field of ICT are necessary to overcome human resource barriers. The local culture that affects the e-readiness of ASN can be changed through changes in organizational culture. Organizational habits using ICT will change habits and encourage civil servants to master ICT

\section{Conclusion}

The results showed that the successful element of e-government development for supporting the improvement of the competence of Civil Servants in the Regional Personnel Board of Timor Tengah Utara Regency includes support, capacity, value, willingness, and local culture which are still not optimal. The elements of support, capacity and local culture have not supported the development of e-government, while the elements of value and willingness have supported the development of e-government.

Obstacles in the development of e-government to support the development of the competence of the State Civil Apparatus in the scope of work of the Regional Personnel Agency of North Central Timor Regency include e-readiness, the absence of a legal governing the implementation of e-government, limited financial resources, infrastructure resources and human resources and local culture of civil servants who tend to be lazy to improve their ability to master Information and Communication Technology

\section{Suggestions}

Suggestions that can be given by researchers based on the research results are:

1. Regional Civil Service Agenciess need to encourage regional heads to immediately issue regulations or legal umbrellas governing the implementation of e-government.

2. Regional Civil Service Agency is necessary

Build cooperation with Regional Apparatus Organizations in Finance activities to support the implementation of e-government.

3. Regional Civil Service Bodies should be able to plan budget related to e-government development.

4. Regional Civil Service Bodies and other Regional Apparatus Organizations need to increase the number of admin/operator staff with a background in informatics engineering education and optimize existing personnel by increasing their capacity through training.

5. Regional Civil Organizations need to register their employees who are not computer literate and provide a short training and require them to have e-mail.

\section{REFERENCES}

1. Hasibuan, ZA, Santoso, HB. 2005. Standardisasi aplikasi egovernment untuk instansi pemerintah. Prosiding Konferensi Nasional Teknologi Informasi dan Komunikasi Indonesia. ITB, 3-4 Mei 2005.

2. Rakhmawanto, Ajib. 2017. Pengembangan Sistem Manajemen Aparatur Sipil Negara Berbasis Teknologi 
Informasi: Analisis Implementasi dan Hambatan. Civil Service, 11(2): 13-25.

3. BKN, 2019. Statistik PNS. Diakses dari https://www.bkn.go.id/statistik-pns pada tanggal 29 November 2019.

4. Paath, Carlos K.Y. 2018. "Jumlah ASN di Indonesia 4.351.490 Orang” dalam Berita Satu, pada 29 Oktober. Tersedia secara online juga di: https:// www.beritasatu.com/nasional/515506/ jumlah-asndiindonesia-4351490-orang diakses pada tanggal 1 Desember 2019.

5. Sophia, Bethy. 2013. Pengembangan Kompetensi Sumber Daya Aparatur Daerah Untuk Meningkatkan Kinerja Aparatur Pada Kantor Badan KepegawaianDaerah(BKD) Kabupaen Malinau. Jurnal Administrasi Reform, 1(1), Hal: 23-40.

6. Indrajit, Richardus Eko. 2016. Electronik Goverment. Diakses dari https://www.academia.edu/3010 0450/Electronic_Government pada tanggal 6 Maret 2020.

7. Atthahara, Haura. 2018. Inovasi Pelayanan Publik Berbasis E-Government : Studi Kasus Aplikasi Ogan Lopian Dinas Komunikasi Dan Informatika Di Kabupaten Purwakarta. Jurnal Politikom Indonesiana, 3(1): 66-77.

8. Setiani, Yulinar Ayu, dan Maesaroh. 2018. Analisis Pengembangan E-Government Di Kabupaten Kendal.Jurnal Kebijakan Publik dan Tinjauan Manajemen, 7(3) : 1-9.

9. Hardjaloka, Loura. 2014. Studi Penerapan e-Goverment di Indonesia dan Negara Lainnya Sebagai Solusi Pemberantasan Korupsi di Sektor Publik. Jurnal Rechtsvinding, 3(3): 435-452.

10. Batubara, Eka Rolania, dan Herlina Helmy. 2019. Analisis Pengembangan ElectronicGovernmentMelalui Penyelenggaraan Website Di Pemerintahan Daerah Kabupaten Padang Pariaman. Jurnal Eksplorasi Akuntansi, 1(4): 1666-1686.

11. Purwandani, Sri, Maesaroh, Rihandoyo. 2012. Analisis Penerapan Electronic Government Di Kabupaten Pati. Journal Of Public Policy And Management Review, 1(2): 1-38.

12. Lestari, Sinta Denna, dan Nina Widowati. 2018. Analisis Pengembangan E-Government di Kota Salatiga. Journal of Public Policy and Management Review, 7(2):1-15. Diunduh dari https://ejournal3.undip.ac.id/index.php/jppmr/article/view/19951 pada tanggal 18 Mei 2020

13. Sosiawan, Edwi Arief. 2008. Evaluasi Implementasi E-Government Pada Situs Web Pemerintah Daerah Di Indonesia : Prespektif Content Dan Manajemen. Seminar Nasional Informatika (Semnasif), 1(5): 99-108 Diunduh dari http://jurnal.upnyk.ac.id/index.php/se mnasif/article/view/759 pada tanggal 13 Maret 2020.

14. Ordiyasa, IW. 2015. Kegagalan Penerapan E-Government di Negara-Negara Berkembang. Seminar Nasional Teknologi Informasi dan Multimedia. Yogyakarta: 6-8 Februari 2015. Hal : 55-59. Diunduh dari https://www.researchgate.net/publicati on/280319408_KEGAGALAN_PENE GOVERMENT_DI_NEGARA-NEGARA_BERKEMBANG pada tanggal 17 Mei 2020.

15. Nur, Emilsyah. 2014. Penerapan E-Government Publik Pada Setiap Skpd Berbasis Pelayanan Di Kota Palu. Jurnal Penelitian Komunikasi dan Opini Publik, 18(3): 265-280

16. Margiyanti. 2016. Upaya Pengembangan E-Government Dalam Pelayanan Publik Pada Dinas Koperasi Dan UKM Kabupaten Pringsewu. Konferensi Mahasiswa Sistem Informasi (KMSI), 4(1): 499504.Diunduh dari http://ojs.stmikpringsewu.ac.id/index.p hp/procidingkmsi/article/view/172 pada tanggal 21 Mei 2020.

17. Sitokdana, Melkior Nikolar Ngalumsine. 2019. Evaluation Of The Information Quality Of E-Government Websites Of The Provincial Governments Of Eastern Indonesia (Case Study: Ntt Province, Maluku, North Maluku, West Papua And Papua). Advances in Economics, Business and Management Research, 100 :231241.

18. Azwaria, Ainun. Penerapan E-Government Di Kantor Sekretariat Daerah Kota Makassar. Skripsi. Universitas Hasanuddin, Fakultas Ilmu Sosial dan Ilmu Politik, Jurusan Ilmu Administrasi, Makasar.

19. Hidayat, Anto, Siti Aisyah dan Sri Weningsih. 2011. Implementasi E-Government Dalam Administrasi PemerintahanDiKabupaten Banyumas. Laporan Penelitian. Fakultas Ilmu Sosial dan Ilmu Politik, Jurusan Ilmu Administrasi, Universitas Terbuka.

20. Angguna, Yordan Putra, A. Yuli Andi Gani dan Sarwono. 2017. Upaya Pengembangan E-Government Dalam Pelayanan Publik Pada Dinas Koperasi Dan Ukm Kota Malang. Jurnal Administrasi Publik (JAP) 3(1): 80-88.

21. Masyhur, Firdaus. 2013. Peran Sumber Daya Manusia Dalam Implementasi E-Government Pada Pemerintah Kota Parepare. ResearchGate. Diakses dari https://www.researchgate.net/publicati on/327719836_The_Role_of_Human_ government in Parepare Per an Sumber Daya Manusia Dalam I mplementasi E-overnment Pada P emerintah_Kota_Parepare pada tanggal 16 Mei $20 \overline{2} 0$.

22. Arif, MS, Larasati, E, dan Rihandoyo. 2013.Analisis Pengembangan Electronic GovernmentMelalui Penyelenggaraan Website di Kabupaten Kudus. Journal Of Public Policy And Management Review, 2(4): 34-45. 
23. Kumar V, Mukerji B, Butt I and Persaud A. 2007. Factors for Successful eGovernment Adoption: a Conceptual Framework. The Electronic Journal of e-Government, 5(1):63-76.

24. Napitupulu, Darmawan. 2015. Kajian Faktor Sukses Implementasi E-Government Studi Kasus: Pemerintah Kota Bogor. Jurnal Sistem Informasi, 5(3): 229-236

25. Pemerintah Indonesia. 2003. Instruksi Presiden Nomor 3 Tahun 2003; Tentang Kebijakan dan Strategi Nasional Pengembangan E-Goverment. Jakarta: Sekretariat Negara.

26. Mustafid, Hidayat. 2017. Peningkatan Kinerja Aparatur Sipil Negara Melalui Budaya Organisasi. Tarbawi, 3(1): $1-14$.

27. Ananto, Nugroho. 2005. Peningkatan Kinerja dan Pengembangan SDM Profesional (Kiat Sukses Dalam Mengatasi Hambatan). Bandung : Sinergi Managing Partner-Sinergi Consulting.

28. Rozikin, Mochammad, Wa Hesty, dan Sulikah. 2020. Kolaborasi Dan E-Literacy: Kunci Keberhasilan Inovasi E-Government Pemerintah Daerah. Jurnal Borneo Administrator, 16(1): 61-80.

29. Riley, Thomas B. 2002. Change Management, E-Governance, and The Relationship to E-Government. Commenwealth Centre for Electronic Governance. Diakses dari http://www.rileyis.com/publications/re search_papers/ChangeManagement-and-EGOV.htm pada tanggal 28 Februari 2020.

30. Nugraha, Kristiawan.2018. Perancangan Sistem E-Government untuk Memperkenalkan Potensi Daerah dan Investasi Kabupaten Rembang. Jurnal AMIK JTC/Infokam, 11(4):19-27 Diunduh dari http://amikjtc.com/jurnal/index.php/jurnal/article/view/73/68 pada tanggal 21 Maret 2020.

31. Susanto, Anton. 2011. Analisis Citizen E-Readiness Dalam Pengembangan Desa Berbasis Teknologi Informasi. Jurnal Masyarakat Telematika dan Informasi, 2(1): 61-74. Diakses dari https://mti.kominfo.go.id/index.php/mti/article/view/19 pada tanggal 4 Juni 2020. 